\title{
Circular Economy and Urban Waste Resources Recycling
}

\section{Cheng Luo}

School of Management, Guangdong University of Technology, Guangzhou, China

E-mail for correspondence: $1767300161 @$ qq.com

Received: Aug 7, 2014;

Accepted: Aug 25, 2014;

Published: Aug 30, 2014

Source of Support: Nil

Conflict of Interest: None Declared

\begin{abstract}
With the rapid development of our social economy, the speeding up of urbanization and the rapid increase of people's living standard, the production and living garbage also increases rapidly and have more obvious bad influence on people's health. Such problems as environmental pollution gradually led to the attention of the society from all walks of life. The work of living garbage prevention and control has made great progress. But the level of Living garbage classification and recovery and the processing capacity are relatively lag. So the applicability of the life garbage disposal technology to solve the living garbage is a very important problem.
\end{abstract}

Keywords: Circular economy; urban waste, waste resources recycling

\section{THE STATUS QUO OF URBAN GARBAGE POLLUTION IN CHINA, AND THE TRAIN OF THOUGHT TO SOLVE THE PROBLEM}

Garbage pollution is very serious in our country. With the increasing of urban population, garbage output continues to grow. Environmental pollution has become the shackles of the healthy development of the city, resident's quality of life, and our effort to build a well-off society in an all-round way.

In the face of pressing the ecological environment, the Chinese government has realized the seriousness of the municipal waste problem, and has increased the intensity of the investment and management. Although the urban waste management has made great achievements, but it still cannot adapt to the need of city construction and development, and the circulation economic theory provides an effective way to solve the problem.

The development of circular economy is of great significance to solve the problem of municipal waste in China. First of all, through the waste reuse, recycling economy has reached the purposes of reduction of the city garbage; Second, the circular economy can mitigate the pollution of urban environment; Third, the development of circular economy is an important measure to promote the industrialization of city garbage it can not only solve the problem of environment, but also create a large number of new jobs. In a word, the development of circular economy is the important ways to solve the urban environment pollution, to realize industrialization of waste disposal and to realize the goal of reduction, recycling and harmless, and is of great importance for ecological city construction in China.

\section{THE PROBLEMS EXISTING IN THE COURSE OF URBAN GARBAGE DISPOSAL IN OUR COUNTRY}

In recent years, the Chinese government has been paid close attention to the urban environment and began to formulate relevant laws, regulations and administrative measures, but many deficiencies still exist in the practical work.

\section{LAWS AND REGULATIONS IS NOT SOUND}

The development of circular economy is the fundamental way to solve the problem of municipal waste in China. It needs all kinds of new technology as the support, but also the guarantee of laws and regulations. But, the regulations for the treatment of urban garbage issued late in our country. The first "cleaner production promotion law" adopted only in October 2002. In recent years, our government successively promulgated and implemented regulations , such as "the law on the prevention and control of environmental pollution by solid waste" and "the regulations on the administration of urban city appearance and environmental sanitation" , but the lack of corresponding "method" and the detailed rules for the implementation, brings difficult management according to law. In addition, China's existing laws and regulations in general belong to pollution prevention legislation mode, and has not yet been carried out on the whole process of economic operation cycle legislation, and lack the legal 
constraints about the responsibility and obligation for producers and consumers.

\section{THE MANAGEMENT SYSTEM IS BADLY IN NEED OF REFORM}

To promote the development of circular economy and to solve the problem of urban garbage in our country, the government's macro management system needs reform. For a long time, urban garbage treatment in China has been swept by the government as a social public welfare undertakings and the sanitation department is a watchdog, and management and execution unit. On the one hand, it can make the result of insufficient funds. On the other hand, the city sanitation management team is complex, multi-level and non-concentration, wrangling with each other and failing to make full use of valuable human, material and financial resources.

\section{THE ECONOMIC POLICIES AND MEASURES ARE IMIPERFECT}

From the perspective of economic analysis, city garbage is the negative external effects of the society and environment caused by manufacturers and merchants. And the increasing urban garbage is external manifestation of market failure. Aiming at the problems in the process of city garbage treatment in China, the existing laws and regulations is not sound, and is badly in need of reform. Under the current urban waste management system, there are two ways to solve problem of the externalities of urban waste, including to charge residents on city garbage disposal and to levy a tax for manufacturer on municipal waste. This kind of phenomenon, on the city garbage problem, can tell us that the economic policies and measures to promote the development of circular economy in our country are imperfect.

THE PUBLICITY AND EDUCATION WORK FOR ENVIRONMENTAL PROTECTION IS INADEQUATE

Publicity and education is the important tool to improve the development of circular economy. If there is no universal improvement of environmental awareness, to develop circular economy is very difficult. The reason why the current city garbage problem is increasingly serious is that city dwellers' understanding of circular economy, sustainable consumption, green consumption and the concept of urban garbage classification are not deep. The publicity and education work for environmental protection is Inadequate.

\section{CIRCULAR ECONOMIC AND SOCIAL MODEL HAS NOT YET FORMED}

"High-pressure \&high-concentration \&low-viscosity" way of extensive economic growth in China, and the extravagance and waste with the improvement of residents living standards, make that "three wastes" emissions high. On the one hand, precious resources cannot be made fully use; on the other hand, the accumulation of municipal waste and emissions has become a serious pollution source. This phenomenon indicates that the mode of circular economy and society is still far behind. In most cities in our country, at present it still is given the priority for mixed collect garbage collection work, the garbage classification and classified collection work is not common. But if we want to realize the recycling of the waste, and let "ghost" become "treasure", classified collection is the only way.

\section{Suggestions for City Garbage Problem}

\section{ESTABLISH PERFECT LAWS AND REGULATIONS SYSTEM}

"Reduction, recycling and harmless" in the city's disposal affairs involves social aspects and is a systemic engineering with sustainable development. Among them, to formulate the perfect legal system to solve the problem of municipal waste is the basis of the system engineering. There are many imperfections in the laws and regulations of the urban garbage treatment in China. So we must have a comprehensive study, from the industrial development, economic policy, science and technology innovation, etc, and formulate laws and regulations to promote "reduction, recycling and harmless" in the city's disposal affairs and constantly improve them, to promote the development of circular economy, solving the problem of municipal waste.

\section{IMPROVE THE RELEVANT POLICIES AND MEASURES}

The current resource price distortion is the serious obstacle for solving our country city garbage problem. In order to promote rapid economic development, in terms of the development and use of natural resources, Subsidy system widely implemented in our country. Due to this situation, waste recycle utilization is lack of motivation, because recycling is more cost-effective than to buy new mining resources. In the face of this situation, first of all we should phase out subsidy system, and use economic means to make resource prices reflect the true value of ecology and economics. In terms of the use of environmental resources, environmental resources are joint property and property right is not exclusive. If common property resources open to every user, and there are no plans to use, it can lead to early use, misuse, and excessive use of resources. To prevent this kind of phenomenon, we can levy joint property tax from users.

\section{PROMOTE THE LEVEL OF MARKETIZATION OF URBAN WASTE MANAGEMENT}

In charge of municipal waste management, the government restrains each main body mainly by the power of administration and moral behavior, but the practice has proved its effect is not good. A single method for waste management by government investment is not enough. We must find new sources of money. Investors are bound to change the rules of the game and the 
adjustment of government functions is an important link. City sanitation department operating functions should be completely stripped out to the market and keep standards and supervisory functions. We can establish a waste management company instead of the original urban waste management operating part and receives the original assets and functions. Market development is a process, and we can firstly establish a completely state-owned enterprise to build a platform for the capital market to participate in. At last, the market decides the choice of waste management service provider. From the point of the present situation, we must find value from the garbage and make a profit by management, to make better management of municipal waste. And the existing processing technology provides a benefit from the garbage. A particularly important point in the process of urban garbage disposal problem is garbage property rights. So we should research and determine waste property. In fact, Scavengers become useful rubbish property owners, but they are not responsible for the processing of useless junk. The winner of the benefit does not assume obligations, and the government undertakes the duty of the useless garbage processing. Therefore, if we want to make enterprises to participate in urban waste management, we must ensure that the waste (full sense of the garbage) is owned by investors, and confirm that in the form of legislation.

\section{EXTENDED PRODUCER RESPONSIBILITY AND REALIZE THE INDUSTRIALIZATION OF MUNICIPAL WASTE}

According to the view of economics, in terms of management of quasi-public products, the government should take the way of industrialization. And for waste treatment industrialization, the most fundamental is established a special organization for one-stop service on the basis of the extended producer responsibility, eventually there should be a garbage processing industrial chain. To extend producer responsibility, is not only the way to clear the power and responsibility of the municipal waste producers, emitter and collector, and can also helps to establish social constraints of effective incentive mechanism.

\section{TO STRENGTHEN THE CULTIVATION OF PUBLIC CONSCIOUSNESS}

Consumers' understanding and broad participation are the key factors of successful implementation of extended producer responsibility principle. Consumers' classified disposal of garbage is the basic guarantee of the implementation of extended producer responsibility. Classification dustbin has also appeared in some large and medium cities in China, but residents who classify living garbage are rare. According to this problem, strengthening propaganda and education is essential. Even in Germany and Japan where the environmental protection consciousness is very strong, the governments also attach great importance to strengthen propaganda and education to improve people's environmental consciousness. Publicity and education activities can't simply become a mere formality, but should be fully into the community and schools. Publicity and education activities often gain the maximum efficiency only after the true success to mobilize the enthusiasm of the masses.

\section{CONCLUSION}

Here is just the beginning. In the peacetime, the environmental protection industry will promote the development of the society. The city life garbage disposal industry scale is very large, and we believe that garbage will at last become precious useful resources.

\section{REFERENCES}

Alam, M., Willems, P., \& Alam, M. (2014). Comparative Assessment of Urban Flood Risks due to Urbanization and Climate Change in the Turnhout Valley of Belgium. ABC Journal Of Advanced Research, 3(1), 14-23. Retrieved from http://journals.abc.us.org/index.php/abcjar/article/view/5.2

Ataur Rahman, A., \& Khan, A. (2014). Measuring Underground Economy of Bangladesh: Transaction Approach. Global Disclosure Of Economics And Business, 1(2), 9-17. Retrieved from http://ischolar.in/index.php/GDEABC/article/view/54515

Awan, A. (2014). Shifting Global Economic Paradigm. Asian Business Review, 4(3), 35-40. Retrieved from http://ischolar.in/index.php/ABRABC/article/view/58256

Awan, A., \& Khan, R. (2014). The Enigma of US Productivity Slowdown: A TheoreticalAnalysis. American Journal Of Trade And Policy, 1(1), 7 15. Retrieved from http://journals.abc.us.org/index.php/ajtp/article/view/1.1

Gebrehiwot, K. (2014). The impact of human capital development on economic growth in Ethiopia:Evidence from ARDL approach to cointegration. American Journal of Trade And Policy, 1(2), Full Thesis. $\quad$ Retrieved from http://journals.abc.us.org/index.php/ajtp/article/view/Gebr ehiwot

Huang X. J., "Circularly Economy: Industry Mode and Policy System",[J],Nanjing University Press, 2004-10

Hussain, M., \& Mushtaq, M. (2014). Awareness about Hospital Wastes and its Effects on the Health of Patients in District Dera Ghazi Khan. Asian Journal Of Applied Science And Engineering, 3(8), 41-50. doi:10.15590/ajase/2014/v3i8/54483

Li N., "Out of the Dilemma-Study on Regional Pattern of Urban Employment Capability and Regional Measures in the Northeastern Area of China",[J],The Time Literature \& Art Press, 88, 2005

Li Z. Q., "Thoughts about developing recycling-based economy",[J],China Population Resources and Environment, 12(4):51-56, 2002

Maina, P. (2013). Improving Lime's Reactivity Towards Flue Gas Desulfurization by using Fly Ash, Bottom Ash and Waste Activated Sludge. ABC Journal Of Advanced Research, 2(1), 8-19. Retrieved from http://journals.abc.us.org/index.php/abcjar/article/view/3.1

Pen P. and Ding D., "Analysis of circular economy based on system",[J],System Science College Journal, 71-73, 2006

Qamruzzaman, M., \& Ferdaous, J. (2014). Building a KnowledgeBased Economy in Bangladesh. Asian Business Review, 4(3), 41$49 . \quad$ Retrieved fromhttp://ischolar.in/index.php/ABRABC/article/view/58259

Trisha SH and Jinia MA. 2014. Mud in Urban Context: A Study on Rammed Earth as Building Material in Dhaka City Asian Journal of Applied Science and Engineering, 3, 9-19.

Yang H. Z., "Try to talk about our country circular economy law and system backing",[J],Theories Journal, 7:14-15,2006 